Marta Przygodzkal, Ewa Mikulak', Tomasz Chmielewski ${ }^{l}$, Aleksandra Gliniewicz ${ }^{1,2}$

\title{
REPELLENTS AS A MAJOR ELEMENT IN THE CONTEXT OF PREVENTION OF TICK-BORNE DISEASES
}

\section{REPELENTY JAKO KLUCZOWY ELEMENT PROFILAKTYKI W KONTEKŚCIE ZAPOBIEGANIA CHOROBOM ODKLESZCZOWYM}

\author{
${ }^{1}$ National Institute of_Public Health - National Institute of Hygiene \\ Department of Parasitology and Vector-borne Diseases, \\ ${ }^{2}$ Department of Health Promotion and Prevention of Chronic Diseases \\ Narodowy Instytut Zdrowia Publicznego-Państwowy Zakład Higieny \\ ${ }^{1}$ Zakład Parazytologii i Chorób Przenoszonych przez Wektory \\ ${ }^{2}$ Zakład Promocji Zdrowia i Prewencji Chorób Przewlekłych
}

\begin{abstract}
In Poland, out of the 21 species of ticks described, two species have the greatest epidemiological significance: Ixodes ricinus and Dermacentor reticulatus. Their participation in the transmission of etiologic agents of vector diseases such as Lyme disease, tick-borne encephalitis, human granulocytic anaplasmosis, babesiosis, rickettsiosis and many others is widely known. Due to the often severe and sometimes fatal course of diseases transmitted by ticks, a great deal of emphasis is placed on prophylactic activities, minimizing the possibility of biting and transfering pathogens along with the arachnid saliva. In addition to means of personal protection, including appropriate clothing, protective vaccinations, avoiding tick habitats or body checking after returning from this type of places, one of the most important elements of anti-tick prevention is the use of effective repellents. The key role of using the repellent is to discourage the arthropod from attacking and to prevent it from taking food, as a result of which there is no phenomenon of transmission of pathogens from the hematophage to the host organism. The most commonly used substances with arthropod repellent properties are: N-N-diethylm-toluamide (DEET), 3-(N-acetyl-N-butyl) aminopropionic acid ethyl ester (IR3535), icaridine, permethrin and essential oils. However, it should be remembered that no repellent ever protects $100 \%$ all the time after application - its use should be considered as one of many elements of personal protection in the prevention of tick bites.
\end{abstract}

Key words: repellents, tick-bite prevention, ticks, tick-borne diseases

\section{STRESZCZENIE}

W Polsce spośród opisanych 21 gatunków kleszczy największe znaczenie epidemiologiczne mają dwa gatunki: kleszcz pospolity Ixodes ricinus i kleszcz łąkowy Dermacentor reticulatus. Powszechnie znany jest ich udział w transmisji czynników etiologicznych takich chorób wektorowych jak borelioza z Lyme, kleszczowe zapalenie mózgu, ludzka anaplazmoza granulocytarna, babeszjoza, riketsjozy, a także wielu innych. Ze względu na często ciężki, a niekiedy nawet śmiertelny przebieg chorób przenoszonych przez kleszcze, bardzo duży nacisk kładzie się na działania profilaktyczne, minimalizujące możliwość ukłucia i przekazanie żywicielowi patogenów wraz ze śliną pajęczaka. Oprócz środków ochrony osobistej, takich jak odpowiedni ubiór, szczepienia ochronne, unikanie siedlisk kleszczy czy też przeglądanie ciała po powrocie z tego typu miejsc, jednym z najważniejszych elementów profilaktyki przeciwkleszczowej jest stosowanie skutecznych repelentów. Kluczowa rola zastosowania repelentu polega na zniechęceniu stawonoga do ataku oraz uniemożliwienie mu pobierania pokarmu, w wyniku czego nie występuje zjawisko transmisji patogenów do organizmu żywiciela z organizmu hematofaga. Obecnie najczęściej wykorzystywanymi substancjami o właściwościach odstraszających stawonogi krwiopijne są: N-N-dietylo-

(c) National Institute of Public Health - National Institute of Hygiene / Narodowy Instytut Zdrowia Publicznego - Państwowy Zakład Higieny 
m-toluamid (DEET), ester etylowy kwasu 3-(N-acetylo-N-butylo)aminopropionowego (IR3535), ikarydyna, permetryna oraz olejki eteryczne. Należy jednak pamiętać, że żaden repelent nie chroni w $100 \%$ przez cały czas po zastosowaniu- jego użycie powinno być traktowane jako jeden $\mathrm{z}$ wielu elementów ochrony osobistej w profilaktyce przeciwkleszczowej.

Slowa kluczowe: repelenty, profilaktyka przeciwkleszczowa, kleszcze, choroby odkleszczowe

\section{INTRODUCTION}

Tourism development, conducting various activities in green recreational areas, and people's visit to nonurbanized areas increase the possibility of direct contact with the questing ticks. These arachnids are increasingly found in urban areas, particularly in strongly urbanized areas. The range of ticks is expanding to new areas every year (1). Because of their high epidemiological significance as reservoirs and vectors of transmission (sometimes fatal) diseases, it is very important to prevent bites from these arthropods (2). It is extremely difficult to control the prevalence and population of these arthropods in the environment $(1,3)$. Various activities have been conducted such as arranging space - mowing the grass, removing weeds, cutting down bushes and shrubs, raking and removing fallen leaves, thus limiting the population of rodents and small mammals with a positive effect and thereby reducing the occurrence and activity of ticks. However, these activities can only be performed on small and limited areas up to 1 ha (4), such as park squares and areas around residential buildings, but they are difficult to perform in large forest areas or fallow land. Studies on environmental activities such as reducing the reservoir of animals that are ticks' hosts (cervids, wild boars, and rodents) and transforming natural environments (cutting down dense bushes, mowing grass, and removing weeds) were carried out in large-wooded areas or wild ecotones, which reduced the population of ticks (5).

Killing forest animals alone to reduce the tick population, however, cannot be encouraged and cannot be used as the main (only) method to reduce the number of these arachnids (1). The tick population in the environment can be controlled by using acaricides; however, these treatments are very rarely used due to their harmful effect not only on ticks but also on other animals living in the same environment. Therefore, with limited possibilities to eradicate ticks in the environment, the most important approach is individual protection from ticks $(3,6)$.

\section{INDIVIDUAL PROTECTION AGAINST TICKS - PREVENTIVE ACTIONS}

The most effective way to protect against ticks is to avoid places where ticks live and prevent them from invading humans (7). Other activities of personal protection used to protect against tick bites are as

\section{WSTĘP}

Rozwój turystyki, prowadzenie aktywności na zielonych terenach rekreacyjnych, a także wkraczanie ludności na tereny niezurbanizowane zwiększa prawdopodobieństwo bezpośredniego kontaktu z oczekującymi na żywiciela kleszczami. Pajęczaki te coraz częściej spotykane są na terenach miejskich, niekiedy silnie zurbanizowanych. Zasięg występowania kleszczy z roku na rok rozszerza się o nowe tereny (1). Ze względu na ich duże znaczenie epidemiologiczne jako rezerwuarów oraz wektorów chorób transmisyjnych (niekiedy śmiertelnych), bardzo istotne jest zapobieganie ukłuciom przez te stawonogi (2). Kontrolowanie występowania i liczebności populacji tych stawonogów w środowisku jest wyjątkowo trudne $(1,3)$. Działania takie jak: porządkowanie przestrzeni - koszenie trawy, usuwanie chwastów, przecinka zarośli i krzewów, grabienie i usuwanie opadłych liści; ograniczenie populacji gryzoni i małych ssaków odnoszące pozytywny skutek - ograniczenie występowania i aktywności kleszczy - niestety są możliwe do wykonania tylko na niedużych i ograniczonych terenach do 1 ha (4) takich jak: parki skwery i tereny wokół zabudowań mieszkalnych, ale trudne w przypadku wielkich terenów leśnych, czy ugorów. Istnieją badania dotyczące działań środowiskowych takich jak: redukowanie rezerwuaru zwierząt będących żywicielami kleszczy (jeleniowatych, dzików, gryzoni), przekształcanie środowisk naturalnych (przecinka gęstych zarośli, wykaszanie traw, usuwanie chwastów) prowadzonych na dużych przestrzeniach zalesionych lub dzikich ekotonach, których przeprowadzenie obniżyło liczebność populacji kleszczy (5). Jednak odstrzał zwierząt leśnych wyłącznie po to, aby zredukować populację kleszczy nie może mieć miejsca i nie może być stosowany jako główna (jedyna) metoda zmniejszenia liczby tych pajęczaków (1). Podobnie zwalczanie kleszczy w środowisku za pomocą akarycydów zabiegi te są stosowane bardzo rzadko ze względu na ich szkodliwy wpływ, jaki wywierają nie tylko na kleszcze, ale i żyjące w tym samym środowisku inne zwierzęta. Dlatego przy ograniczonych możliwościach zwalczania kleszczy w środowisku najważniejsza jest ochrona indywidualna $(3,6)$.

OCHRONA INDYWIDUALNA PRZED KLESZCZAMI - DZIAŁANIA PROFILAKTYCZNE

Najskuteczniejszym sposobem ochrony przed kleszczami jest unikanie miejsc, w którym kleszcze żyją 
follows: wearing appropriate clothing, checking the body surface after visiting the areas potentially populated by ticks, and using commercially available effective repellents. $(3,6)$. Surveys conducted during 2012-2013 by the National Institute of Public Health-National Institute of Hygiene (NIPH-NIH) (8) on prevention and anti-tick activities used by people visiting recreational areas of Warsaw and surrounding areas showed that $40 \%$ of respondents use protection attire against ticks (long sleeve shirt, long pants, socks, and full shoes) on a walk in the woods/park, while other people (about $60 \%$ ) do not. After returning from the forest and park area, 59\% respondents did not watch the clothes, while $41 \%$ did not watch the body. Over $44 \%$ of people declared that they found ticks on the body. Ticks were most often located on the legs (41 cases) and the torso ( 31 cases). To the question of how to properly remove a tick from the skin, $47.9 \%$ of people answered incorrectly (8). In a study carried out in the Lublin region, 35\% of respondents declared using a protective outfit to protect against ticks invasion (9). In addition, Asman et al. reported that in Upper Silesia, $90 \%$ of people who visited doctors in health centers to remove an attached tick admitted that they did not use repellents (10). According to previous research, the awareness of tick-borne diseases and the possibility of contracting them among the respondents is low, and simple preventive behaviors are usually underestimated.

\section{TICKS - DANGEROUS ARTHROPODS}

In our geographical region, ticks pose a greater threat to the health and life of people and animals than other blood-sucking arthropods such as mosquitoes or black flies. The role of ticks in the transmission of pathogens is well known and documented in many scientific publications, and tick-borne diseases in Poland are a serious epidemiological problem $(6,11,12)$. In Poland, mosquitoes and black flies as pathogen vectors do not play such a major role as ticks do. In the epidemiological reports published by NIPH-NIH, diseases such as malaria, West Nile fever, and dengue are recorded sporadically, and most often, cases of infections occurred outside the country. In addition, to date, research has not been carried out on the identification and characterization of viruses, bacteria, fungi, and parasites, whose reservoir and vectors may be Polish native species of mosquitoes and flies. All ticks found worldwide (over 900 species) are obligatory temporal parasites of animals and humans (3).

There are 21 species of ticks in Poland, and two of them are well known: common tick (Ixodes ricinus) and meadow tick (Dermacentor reticulatus) (7). The common tick (I. ricinus) occurs throughout Poland. i uniemożliwienie im dokonania inwazji na człowieka (7). Innymi działaniami ochrony osobistej, służącymi do zabezpieczenia się przeciwko ukłuciom kleszczy, jest profilaktyka polegająca na: noszeniu odpowiedniej odzieży, sprawdzanie powierzchni ciała po przebywaniu na terenach potencjalnie zasiedlonych przez kleszcze, oraz stosowaniu skutecznych, dostępnych w sprzedaży repelentów $(3,6)$. Badania ankietowe przeprowadzone w latach 2012-2013 przez Narodowy Instytut Zdrowia Publicznego-Państwowy Zakład Higieny (8) dotyczące profilaktyki i działań antykleszczowych stosowanych przez osoby odwiedzające tereny rekreacyjne Warszawy i okolic wykazały, że 40\% ankietowanych stosuje ubiór chroniący przed inwazją kleszczy (koszula $z$ długim rękawem, długie spodnie, skarpety i pełne buty) na spacerze po lesie/parku, pozostałe osoby (ok. $60 \%$ nie. Po powrocie z terenów leśno - parkowych ubrań nie oglądało $59 \%$, natomiast ciała nie oglądało $41 \%$ ankietowanych. Ponad $44 \%$ osób deklarowało, że znajdowało kleszcze na ciele. Kleszcze najczęściej były lokalizowane na nogach (41 przypadków) i na tułowiu (31 przypadków). Na pytanie jak prawidłowo usunąć kleszcza ze skóry $47,9 \%$ osób odpowiedziało błędnie (8). W badaniach przeprowadzonych na terenie Lubelszczyzny 35\% respondentów deklarowało stosowanie stroju chroniącego przed inwazją kleszczy (9). Ponadto w badaniach Asmana i wsp. na terenie Górnego Śląska, 90\% osób zgłaszających się do lekarzy w ośrodkach zdrowia w celu wyjęcia wkłutego kleszcza przyznało, że nie stosowało repelentów (10). Z przeprowadzonych badań wynika więc, że świadomość dotycząca chorób odkleszczowych i możliwości zachorowania na nie wśród osób ankietowanych jest niska, a proste zachowania profilaktyczne są zazwyczaj bagatelizowane.

\section{KLESZCZE - NIEBEZPIECZNE STAWONOGI}

W naszym regionie geograficznym, kleszcze stanowią większe zagrożenie dla zdrowia i życia ludzi i zwierząt niż inne odżywiające się krwią stawonogi, np. komary, czy meszki. Rola kleszczy w przenoszeniu patogenów jest dobrze poznana i udokumentowana w wielu publikacjach naukowych, a choroby odkleszczowe są w Polsce poważnym problemem epidemiologicznym $(6,11,12)$. W naszym kraju komary i meszki jako wektory patogenów nie odgrywają tak wielkiej roli jak kleszcze. W Meldunkach epidemiologicznych publikowanych przez NIZP-PZH choroby takie jak: malaria, gorączka Zachodniego Nilu, denga, itp. są odnotowywane sporadycznie, najczęściej są to przypadki zakażeń, jakie nastąpiły poza granicami naszego kraju. Ponadto brak jest aktualnych badań, dotyczących identyfikacji i charakterystyki wirusów, bakterii, grzybów i pasożytów, których rezerwuarem i przenosicielami mogą być nasze rodzime gatunki komarów i meszek. 

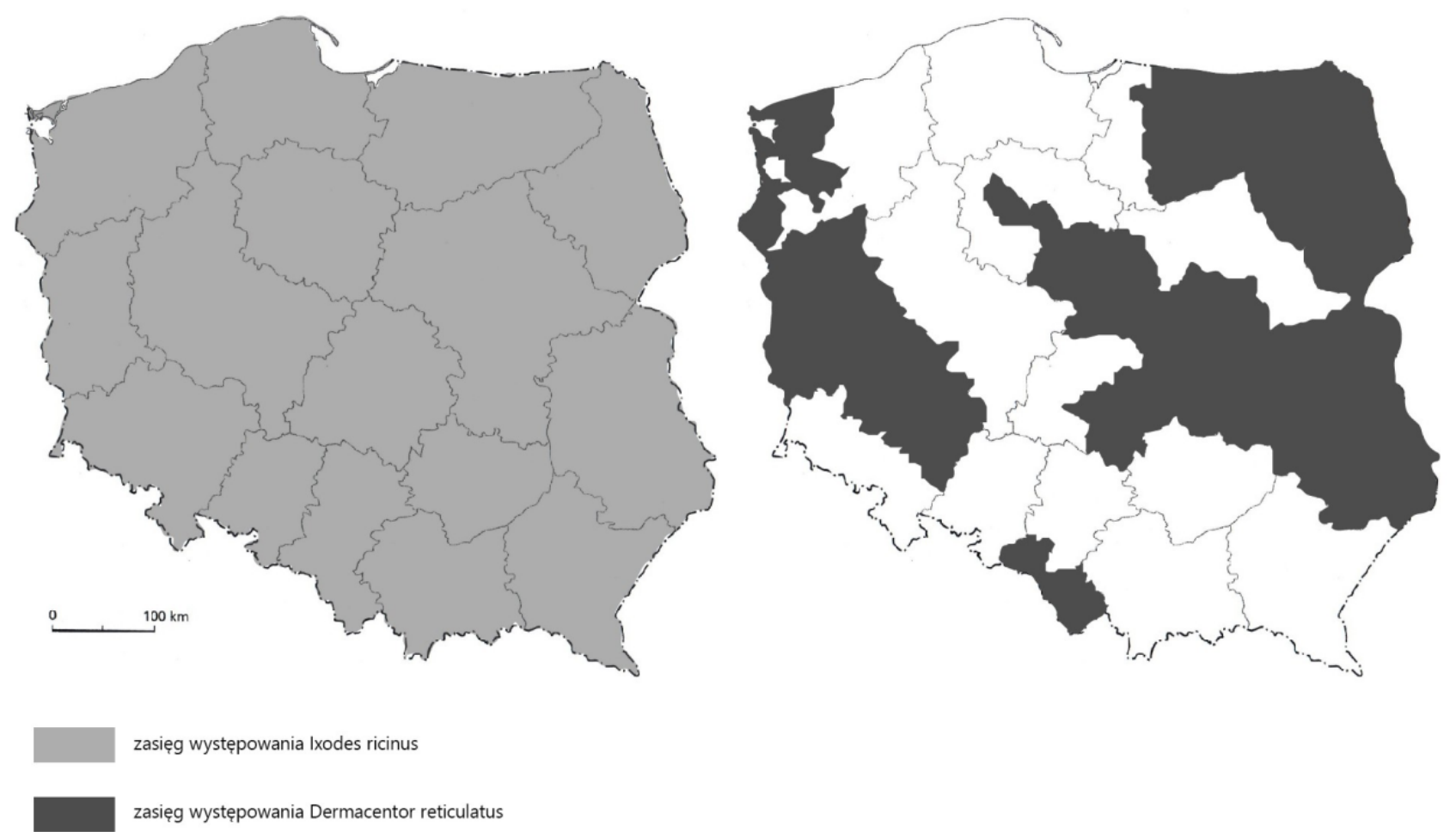

zasięg występowania Ixodes ricinus

zasięg występowania Dermacentor reticulatus

Fig. 1 Distribution of ticks from the species Ixodes ricinus and Dermacentor reticulatus in Poland (own study) Ryc. 1. Rozmieszczenie kleszczy z gatunków Ixodes ricinus i Dermacentor reticulatus na terenie Polski (opracowanie własne)

It occurs in a moderately moist and shady environment, most often in deciduous and mixed forests with rich undergrowth as well as in clusters of bushy vegetation. It gathers in places where it has the greatest likelihood of meeting the host - near forest paths, on the edge of logs, and in transition zones between different types of environments. It rarely inhabits open areas and dry forests (13).

Meadow tick (D. reticulatus) occurs in Poland as two separate populations: eastern and western. Two separate areas of meadow tick occurrence may be associated with the extending transition zone between the oceanic and continental climate in central Poland, which affects the vegetation and associated animal world. Through the middle of Poland, there are borders of the range of a huge number of species of animals and plants; it is estimated that $52 \%$ of species occurring in Poland are transitional, that is, occurring in both the east and west of Poland's borders 14).

The meadow tick $D$. reticulatus inhabits open areas or areas poorly covered with trees and shrubs, and are moderately moist. It prefers natural deciduous forests associated with watercourses or large reservoirs of stagnant water. This species mostly inhabit the riparian forests growing on banks of rivers and lakes as well as meadows on the outskirts of forests with a fairly high level of groundwater. Ticks occurring in their natural environment are ectoparasites of wild animals such as deer, elk, wild boar, and rodents. However, people working in forests (foresters and woodcutters) or
Wszystkie kleszcze żyjące na świecie (ponad 900 gatunków) są obligatoryjnymi, czasowymi pasożytami zewnętrznymi zwierząt i człowieka (3).

W Polsce występuje 21 gatunków kleszczy, a najbardziej znane są dwa: kleszcz pospolity (Ixodes rici$n u s$ ) i kleszcz łąkowy (Dermacentor reticulatus) (7).

Kleszcz pospolity (Ixodes ricinus) występuje w całej Polsce.

Bytuje w umiarkowanie wilgotnym i zacienionym środowisku, najliczniej występuje w lasach liściastych i mieszanych o bogatym podszyciu, a także w skupiskach roślinności krzaczastej. Gromadzi się w miejscach, gdzie ma największa szansę spotkania żywiciela - w pobliżu ścieżek leśnych, na skraju polan i w strefach przejściowych między różnymi typami środowisk. Rzadko zasiedla tereny otwarte i suche bory (13).

Kleszcz łąkowy (Dermacentor reticulatus) występuje na terenie naszego kraju jako dwie osobne populacje: wschodnia i zachodnia.

Dwa oddzielne obszary występowania kleszcza łąkowego mogą być związane z rozciągającą się strefą przejściową pomiędzy klimatem oceanicznym a kontynentalnym na terenie środkowej Polski, co ma wpływ na szatę roślinną i związany z nią świat zwierzęcy. Przez środek Polski przebiegają granice zasięgu ogromnej liczby gatunków zwierząt i roślin, szacuje się, że 52\% gatunków występujących w Polsce ma charakter przejściowy, tzn. występuje zarówno na wschód, jak i na zachód od naszych granic. (14). 
people periodically visiting forests and environments willingly settled by ticks, such as pickers of forestry, hunters, farmers, runners, tourists, and vacationers, may also be exposed to their invasion. Currently, both species of ticks are often found in urban areas, that is, in parks, squares, allotments and backyards, and urban forests, where they live on plants (grasses and low bushes) growing by the paths used by animals and people for walking. It is estimated that in urban areas, the risk of infections of people with pathogens transmitted by ticks is as high as that in forest areas (15). The factor conducive to the expansion of ticks into urban areas is the creation of so-called ecological corridors (strips of shelters, undeveloped river beds, and vast parks with varied vegetation), through which wild animals carrying tick can migrate to the cities.

Ticks can also dwell on dogs traveling with their owners and on large animals transported for commercial or breeding purposes (16).

\section{TICKS AS A VECTOR OF PATHOGENS}

Ticks are vectors of over 60 viruses (of which 20 are etiological factors of human and animal diseases), 11 bacterial pathogens including rickettsial disease causing spotted fevers, and 5 genotypes of Borrelia burgdorferi sensu lato, Anaplasma phagocytophilumetiological factor of human granulocytic anaplasmosis and human babesiosis $(2,12)$.

Pathogens can be transmitted through all life stages of tick. All active stages of I. ricinus can attack humans (13), but nymphs and females are most frequently found to attack humans (17). In contrast, for ticks of the species $D$. reticulatus, man is a rare and rather accidental host (18). If , the attack does occur, the host is parasitized mainly by the adult population of this tick species and less often by nymphs $(19,20)$.

In Poland, Lyme disease is the most common registered tick-borne disease $(6,11)$. Data from epidemiological studies conducted by the Department of Epidemiology of the NIPH-NIH every year shows an upward trend in the number of incidences (Fig. 2): in 2016 , the number of registered cases was 21,220 , whereas in 2017 and 2018, 20,139 and 21,528, respectively, cases were reported. In Europe, as the etiological factor of Lyme borreliosis, two most frequently observed genospecies of Borrelia burgdorferi sensu lato are Borrelia afzelii and Borrelia garinii (21). The infections caused by Borrelia burgdorferi sensu stricto as well as by Borrelia valaisiana and Borrelia lusitaniae, which are most commonly found in coinfection, are less frequently detected $(22,23)$. The abovementioned genospecies belonging to the complex Borrelia burdorferi sensu lato are responsible for "classic" Lyme borreliosis with symptomatology including the nervous
Kleszcz łąkowy D. reticulatus zamieszkuje tereny otwarte albo słabo porośnięte drzewami i krzewami oraz umiarkowanie wilgotne. Preferuje naturalne lasy liściaste związane z ciekami wodnymi lub dużymi zbiornikami wód stojących. Najliczniej zamieszkuje łęgi porastające brzegi rzek i jezior oraz łąki na obrzeżach lasów, o dość wysokim poziomie wód gruntowych. (13).

Kleszcze występujące w swoim naturalnym środowisku są ektopasożytami dzikich zwierząt, tj. jeleni, łosi, dzików, gryzoni, itp. Jednak na ich inwazję mogą być narażeni także ludzie pracujący w lasach (leśnicy, drwale) lub osoby okresowo odwiedzające lasy i środowiska chętnie zasiedlane przez kleszcze, np. zbieracze runa leśnego, myśliwi, rolnicy, biegacze, turyści, wczasowicze.

Obecnie oba gatunki kleszczy są często spotykane na terenach zurbanizowanych: w parkach, na skwerach, ogródkach działkowych i przydomowych oraz lasach miejskich, gdzie bytują na roślinach (trawy, niskie krzewy) rosnących przy ścieżkach, którymi uczęszczają zwierzęta i ludzie udający się na spacery. Szacuje się, że na terenach miejskich zagrożenie zakażeniami ludzi patogenami przenoszonymi przez kleszcze jest tak samo wysokie jak na obszarach leśnych (15). Czynnikiem sprzyjającym ekspansji kleszczy na tereny zurbanizowane jest tworzenie tzw. korytarzy ekologicznych (pasma zadrzewień, niezagospodarowane koryta rzek, rozległe parki o urozmaiconej szacie roślinnej), którymi dzikie zwierzęta wędrują do miast, a wraz z nimi przenoszą się przyczepione do nich kleszcze. Kleszcze łąkowe mogą też bytować na psach, podróżujących ze swymi właścicielami oraz na dużych zwierzętach przewożonych w celach handlowych lub hodowlanych (16).

\section{KLESZCZE JAKO WEKTORY PATOGENÓW}

Kleszcze są przenosicielami ponad 60 wirusów (z których 20 jest czynnikami etiologicznymi chorób człowieka i zwierząt domowych), 11 patogenów bakteryjnych, w tym riketsji wywołujących gorączki plamiste, 5 genogatunków krętków z gatunku Borrelia burgdorferi sensu lato, Anaplasma phagocytophilum - czynnika etiologicznego ludzkiej anaplasmozy granulocytarnej oraz pierwotniaków z rodzaju Babesia, będących czynnikiem etiologicznym ludzkiej babeszjozy $(2,12)$.

Patogeny mogą być przenoszone przez wszystkie stadia rozwojowe kleszczy. Wszystkie aktywne stadia rozwojowe I. ricinus atakują ludzi (13), ale najczęściej znajdowane były nimfy i samice (17). Natomiast dla kleszczy z gatunku $D$. reticulatus człowiek zostaje żywicielem rzadko i raczej przypadkowo (18). Jeśli już tak się stanie, pasożytują na nim głównie osobniki dorosłe, rzadziej nimfy $(19,20)$. 
system, cardiovascular system (heart), the osteoarticular system, and skin. In addition, among the spirochetes of the Borrelia genus, there is a group of bacteria that causes flu-like relapsing fever, in which the occurrence of erythema was rarely observed - a pathognomonic symptom of Lyme borreliosis. The representative of this group is Borrelia miyamotoi, whose genetic material has been detected in I. ricinus ticks in Poland $(24,25,26)$.
W Polsce spośród chorób przenoszonych przez kleszcze najczęściej rejestruje się zachorowania na boreliozę z Lyme $(6,11)$. Dane pochodzące z meldunków epidemiologicznych prowadzonych przez Zakład Epidemiologii Narodowego Instytutu Zdrowia Publicznego - Państwowego Zakładu Higieny z roku na rok wykazują tendencję wzrostową zachorowań (Ryc. 2):

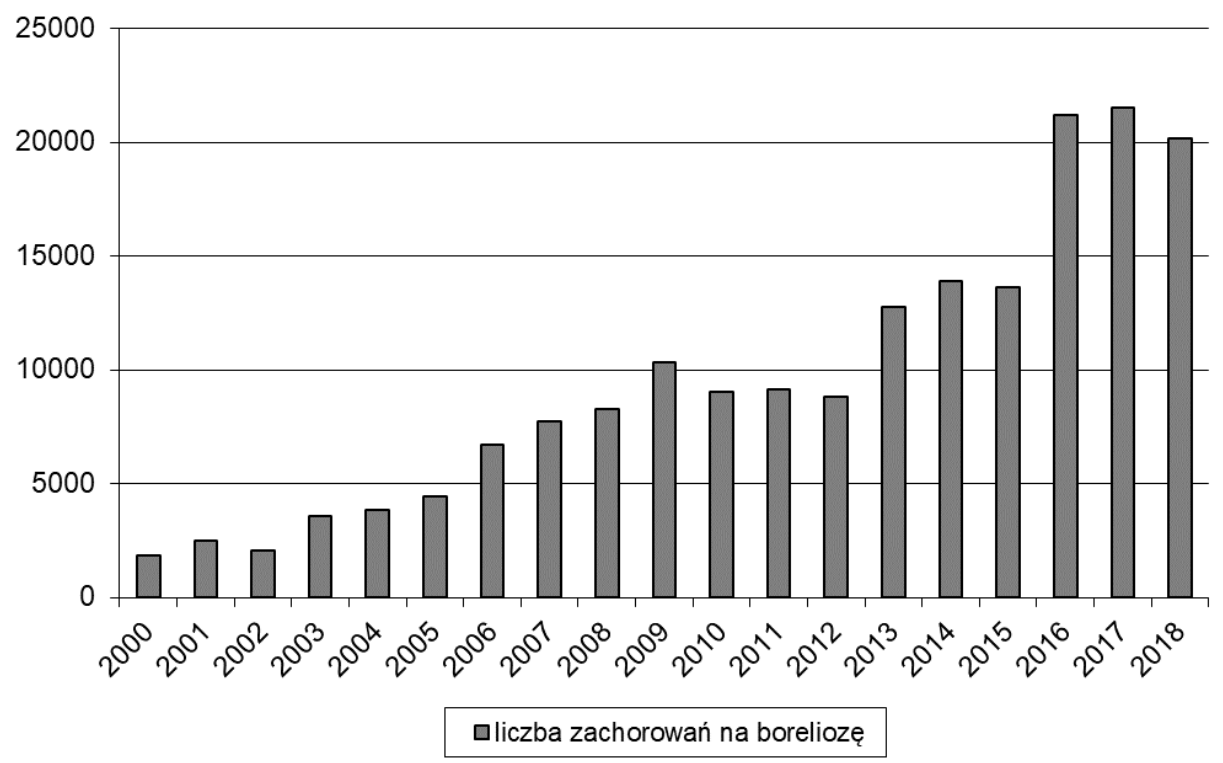

Fig. 2 Number of Lyme disease cases in Poland in 2000-2018 (data from NIPH-NIH)

Ryc. 2 Zachorowania na boreliozę w Polsce w latach 2000-2018 (dane NIZP-PZH)

In addition, tick-borne encephalitis, human granulocytic anaplasmosis, and babesiosis have a serious epidemic importance (Table 1).

Ticks may have a direct negative impact on the host's immunity during feeding, causing lifethreatening tick paralysis and severe allergic reactions (13).

\section{REPELLENTS AS A MAJOR ELEMENT OF ANTI-TICK PROPHYLAXIS}

The use of repellents on the skin may be one of the most effective ways to avoid host-vector contact. It can therefore be assumed that repellents indirectly contribute to the prevention of arthropod diseases (27).

Repellents are properly selected according to factors such as active substances, chemical compounds, and devices emitting sounds and light; they can also be living organisms which, by their action, confuse, discourage, and/or repel animals from places where their presence is particularly undesirable. For repelling blood-sucking arthropods, synthetic and plant origin substances that cause immediate escape from the treated skin or clothing fragment and most importantly - resolution of sting or bite-are used.
W roku 2016 liczba zarejestrowanych przypadków wyniosła 21 220, w 2017 - 21 528, natomiast w 2018 roku zgłoszono 20139 zachorowań. W Europie jako czynnik etiologiczny boreliozy z Lyme najczęściej wymieniane są dwa genogatunki należące do gatun$\mathrm{ku}$ (kompleksu) Borrelia burgdorferi sensu lato $-B$. afzelii i B. garinii (21). Rzadziej wykrywa się zakażenia wywoływane przez $B$. burgdorferi sensu stricto, a także $B$. valaisiana i $B$. lusitaniae, które najczęściej występują w koinfekcjach. $(22,23)$. Wymienione genogatunki należące do kompleksu Borrelia burdorferi sensu lato są odpowiedzialne za wywoływanie „klasycznej" boreliozy z Lyme z symptomatologią obejmującą układ nerwowy, układ krążenia (serce), a także układ kostno-stawowy i skórę. Ponadto wśród krętków rodzaju Borrelia istnieje grupa bakterii wywołujących gorączki powrotne o grypopodobnym przebiegu, w których rzadko obserwowano występowanie rumienia wędrującego - objawu patognomicznego w przebiegu boreliozy z Lyme. Przedstawicielem tej grupy jest m.in. Borrelia miyamotoi, której materiał genetyczny został wykryty w kleszczach Ixodes ricinus na terenie Polski $(24,25,26)$. 
Table I. Pathogens with the highest epidemiological significance transmitted by ticks in Europe (from z „Effect of climate change on medically important ticks population in Europe with respect to distribution and tick-borne diseases. Methods of limiting a contact of ticks with the people. (in) Dhang P. (red.). Climate change impacts on urban pests., modificated)

Tabela I. Patogeny o największym znaczeniu epidemiologicznym przenoszone przez kleszcze na terenie Europy (z „Effect of climate change on medically important ticks population in Europe with respect to distribution and tick-borne diseases. Methods of limiting a contact of ticks with the people.. (w) Dhang P. (red.). Climate change impacts on urban pests., zmodyfikowane)

\begin{tabular}{|c|c|c|c|}
\hline Pathogen & Disease & Vector/s & Occurence \\
\hline $\begin{array}{l}\text { TBE virus } \\
\text { (Flaviviridae) }\end{array}$ & $\begin{array}{l}\text { Tick-borne en- } \\
\text { cephalitis }\end{array}$ & Ixodes ricinus; I. persulcatus & Whole Europe \\
\hline $\begin{array}{l}\text { CCHF virus- } \\
\text { (Nairovirus) }\end{array}$ & $\begin{array}{l}\text { Crimean- Kongo } \\
\text { Hemorrhagic } \\
\text { Fever }(\mathrm{CCHF})\end{array}$ & $\begin{array}{l}\text { Hyalomma marginatum; different } \\
\text { species from genus Hyalomma; } \\
\text { Ixodes ricinus; Dermacentor mar- } \\
\text { ginatus; Haemaphysalis punctata }\end{array}$ & $\begin{array}{l}\text { Albania; Bulgaria; France; Greece; } \\
\text { Hungary; Kosovo; Macedonia; } \\
\text { Moldowa; Portugal; Russia; Turkey; } \\
\text { Ukraine. }\end{array}$ \\
\hline $\begin{array}{l}\text { Bhanja virus } \\
\text { (Bunyaviridae) }\end{array}$ & Bhanja disease & $\begin{array}{l}\text { Haemaphysalis spp;Dermacentor } \\
\text { spp; Hyalomma spp;Amblyomma } \\
\text { spp;Ripicephalus spp; }\end{array}$ & $\begin{array}{l}\text { Southern Europe; Balkans; Romania; } \\
\text { Czech Republic; Portugal; Spain }\end{array}$ \\
\hline $\begin{array}{l}\text { Eyach virus } \\
\text { (Coltivirus) }\end{array}$ & Eyach disease & Ixodes ricinus; I.ventalloi & $\begin{array}{l}\text { Germany; France; Netherlands; } \\
\text { Czech Republic }\end{array}$ \\
\hline $\begin{array}{l}\text { Borrelia burgdorferi } \\
\text { sensu lato: } \\
\text { B. afzelii; B.burgdorferi } \\
\text { s.str; B.garinii; } \\
\text { B.lusitaniae; B.valaisiana }\end{array}$ & Lyme boreliosis & $\begin{array}{l}\text { Ixodes ricinus; I. ; other vectors: } \\
\text { Dermacentor marginatus; Hya- } \\
\text { lomma punctata; Ripicephalus } \\
\text { sanguineus }\end{array}$ & Whole Europe \\
\hline $\begin{array}{l}\text { Borrelia spp. different } \\
\text { than Borrelia burgdorferi } \\
\text { sensu lato }\end{array}$ & $\begin{array}{l}\text { Tick-borne relaps- } \\
\text { ing fever }\end{array}$ & $\begin{array}{l}\text { Soft ticks (Argasidae): Or- } \\
\text { nithodoros spp. } \\
\text { Ixodes ricinus }\end{array}$ & $\begin{array}{l}\text { Greece; Cyprus: Portugal; Sweden; } \\
\text { Germany }\end{array}$ \\
\hline Rikettsia conorii & $\begin{array}{l}\text { Mediterranean } \\
\text { spotted fever }\end{array}$ & Ripicephalus sanguineus & $\begin{array}{l}\text { Southern Europe: Bosnia and He- } \\
\text { rzegovina; Croatia; Greece; France; } \\
\text { Portugal; Slovenia; Spain; Turkey. } \\
\text { Russia; Italy. }\end{array}$ \\
\hline Rickettsia helvetica & $\begin{array}{l}\text { Spotted fever; } \\
\text { cardiac symptoms }\end{array}$ & Ixodes ricinus & Switzerland; Sweden; France; Italy \\
\hline Rickettsia slovaca & $\begin{array}{l}\text { TIBOLA (Tick- } \\
\text { borne lymphad- } \\
\text { emopathy) }\end{array}$ & $\begin{array}{l}\text { Dermacentor spp; Dermacentor } \\
\text { marginatus }\end{array}$ & $\begin{array}{l}\text { Armenia; Austria; Czech Republic; } \\
\text { France; Germany; Hungary; Italy; } \\
\text { Lithuania; Portugal; Russia; Slova- } \\
\text { kia; Spain; Switzerland. }\end{array}$ \\
\hline $\begin{array}{l}\text { Anaplasma (Erlichia) } \\
\text { phagocytophilum }\end{array}$ & $\begin{array}{l}\text { Human granu- } \\
\text { locytic anaplas- } \\
\text { mosis }\end{array}$ & Ixodes ricinus & $\begin{array}{l}\text { Belgium; Bulgaria; Czech Republic; } \\
\text { Denmark; Germany; Greece; Ireland; } \\
\text { Italy; Netherlands; Norway; Poland; } \\
\text { Portugal; Russia; Slovenia; Spain; } \\
\text { Sweden; Sweden; United Kingdom }\end{array}$ \\
\hline Babesia spp. & Human babesiosis & $\begin{array}{l}\text { Ixodes spp; Dermacentor spp; } \\
\text { Ripicephalus spp. }\end{array}$ & $\begin{array}{l}\text { Ireland; France; Poland; Portugal; } \\
\text { Russia; Switzerland; United Kingdom }\end{array}$ \\
\hline
\end{tabular}

The use of repellents against mosquitoes, ticks, and flies ensures temporary limitation of contact with these arthropods as well as protection against their bites. Many factors can affect the effectiveness of repellents used on the skin. The most important of these factors are the chemical structure of the active substance and the properties of the repellent formulation. In addition, physical factors such as temperature and humidity, condition of the skin (thickness of the skin, damage
Duże znaczenie epidemiczne ma również kleszczowe zapalenie mózgu (KZM), ludzka anaplazmoza granulocytarna oraz babeszjoza.

Kleszcze podczas żerowania mogą bezpośrednio negatywnie oddziaływać na organizm żywiciela, powodując m.in. zagrażający życiu paraliż kleszczowy, a także silne odczyny alergiczne (13). 
to the surface of the skin and other skin tissues), the number of sudoriferous glands, and the intensity of perspiration (e.g., intensive perspiration may shorten the time of effective protection). Therefore, it is very important to use the repellent in accordance with the instructions (method of use) as provided on the labels. The duration of protection that repellent can provide depends on the chemical properties of the compound, environmental characteristics (temperature, time of day, wind speed, light, and humidity), potential host characteristics (sweating, skin condition, individual sensitivity, nutrition, mobility, and diseases such as diabetes), and the tick species

Before World War II, several preparations were available to repel mosquitoes and were also used against other blood-borne arthropods. These preparations were based on natural vegetable oils, mainly citronella oil extracted from lemongrass Cymbopogon nardus. In 1929, dimethyl phthalate (DMP) was developed, and in 1937, patented indalon was developed, which was widely used in the 50 s and 60 s in the US, until the introduction of products such as N-N-diethyl-mtoluamide (DEET) (28).

Currently, repellents may contain synthetic or natural active substances. The literature data show that the following synthetic active substances are most commonly used in repellents: DEET; 3-(N-acetyl-N-butyl) aminopropionic acid, ethyl ester (IR3535); and 1-piperidinecarboxylic acid (KBR 3023, Icaridin); the effectiveness of these substances has been confirmed in studies.

\section{N-N-DIETHYL-M-TOLUAMIDE (DEET)}

$\mathrm{N}$-N-diethyl-m-toluamide is an active substance with a broad spectrum of activity and most frequently used as a component of repellents. The commercial repellents available in Poland most often contain DEET in concentrations ranging from $7 \%$ to $35 \%$. Repellants with formulations containing 50\% and even $100 \%$ DEET for use in special conditions are also commercially available. Formulations containing 30\% DEET provide $100 \%$ protection against ticks for over 3 hours (own tests carried out on D. reticulatus ticks). DEET is considered as a "gold standard" compared to other repellents. However, it is quite a controversial substance. Some studies have found that DEET is easily and quickly absorbed by human skin. Absorption of this substance occurs at the level of $0.8 \% / \mathrm{h}$; in addition, the substance accumulates in the skin and fatty tissues for 1-2 months (29). Wróblewska-Łuczka et al. analyzed the possibility of DEET accumulation in forestry workers using repellents daily and found that in repeated doses, DEET does not accumulate in the surface layers of the skin and is excreted in urine and feces (30). It has also been found that excessive or inappropriate use of products with this

\section{REPELENTY JAKO KLUCZOWY ELEMENT PROFILAKTYKI ANTYKLESZCZOWEJ}

Stosowanie repelentów na skórę może być jednym z najbardziej skutecznych sposobów na uniknięcie kontaktu wektor - gospodarz. Można więc przyjąć, że repelenty przyczyniają się pośrednio do zapobiegania chorobom przenoszonym przez stawonogi (27).

Repelenty to właściwie dobrane czynniki, takie jak: substancje aktywne, związki chemiczne, urządzenia emitujące dźwięki, światło, mogą być to również organizmy żywe, które swoim działaniem dezorientują i zniechęcają oraz odstraszają zwierzęta z miejsc, w których ich obecność jest szczególnie niepożądana. Do odstraszania stawonogów krwiopijnych używane są substancje syntetyczne i pochodzenia roślinnego, które wywołują natychmiastową ucieczkę z traktowanego fragmentu skóry lub odzieży i co najważniejsze - rezygnację z ukłucia lub ugryzienia. Stosowanie środków odstraszających komary i kleszcze oraz meszki to realna gwarancja czasowego ograniczenia kontaktów z tymi stawonogami, a także ochrony przed ich ukłuciami.

Istnieje wiele czynników mogących wpływać na skuteczność repelentów stosowanych na skórę. Najważniejszymi z nich są budowa chemiczna substancji aktywnej oraz właściwości formulacji repelentu. Istotny wpływ mają ponadto czynniki fizyczne takie jak: temperatura i wilgotność powietrza oraz kondycja skóry (grubość skóry, uszkodzenia powierzchni naskórka i innych tkanek skóry), liczba gruczołów potowych i intensywność pocenia się (np. intensywne wydzielanie potu może skrócić czas skutecznej ochrony). Bardzo ważne jest stosowanie repelentu zgodnie ze wskazówkami (sposobem użycia) zamieszczonych na etykietach. Czas ochrony, jaką może zapewnić repelent jest różny. Zależy od właściwości chemicznych związ$\mathrm{ku}$, cech środowiska (temperatura, pora dnia, szybkość wiatru, światło, wilgotność), cech potencjalnego żywiciela (pocenie się, kondycja skóry, indywidualna wrażliwość, odżywianie się, ruchliwość, choroby, np. cukrzyca) oraz gatunku kleszcza.

Przed II wojną światową dostępnych było kilka preparatów odstraszających komary, ale stosowano je również przeciwko innym stawonogom krwiopijnym. Były oparte na naturalnych olejkach roślinnych, głównie olej$\mathrm{ku}$ citronellowym pozyskiwanym z trawy cytrynowej Cymbopogon nardus. W 1929 opracowano DMP (ftalan dimetylu), a w 1937 opatentowano indalon, szeroko stosowany w latach 50. i 60. w USA, aż do wprowadzenia środków z DEET (N-N-dietylo-m-toluamid) (28)

Obecnie w skład repelentów mogą wchodzić substancje czynne syntetyczne lub pochodzenia naturalnego. $\mathrm{Z}$ danych $\mathrm{z}$ piśmiennictwa wynika, że w repelentach najczęściej stosowane są następujące syntetyczne substancje aktywne, tj.: N-N-dietylo-m-toluamid 
active substance may involve the following side effects: encephalopathy, convulsions, coma, and skin irritation (31). Higher concentrations of DEET dissolve plastics; therefore, repellent preparations with this substance should not be used on clothing, footwear, etc.

\section{3-[N-BUTYL-N-ACETYL]-AMINOPROPIONIC ACID, ETHYL ESTER (IR 3535)}

Another active substance frequently used in repellents is 3-(N-butyl-N-acetyl-aminopropionic acid, ethyl ester (IR3535), known under the name EBAAP. It has been used in Europe since 1970 and in the USA since 1999. It is effective not only for ticks but also for mosquitoes, tsetse (Glossinidae), horse flies (Tabanidae), and black flies (Simuliidae). IR3535 also repels wasps. Toxicological studies have shown good skin tolerance and general safety (32). In preparations registered in Poland, this active substance usually occurs in a concentration of 7-20\%. Studies have shown that IR3535 used in preparations at a concentration of $20 \%$ has a long-lasting effect of repelling Amblyomma americanum ticks - up to 12 hours (33).

\section{ICARIDIN}

The component of repellents is sometimes icaridin also known as picaridin, KBR 3023, or Bayrepel, which was first synthesized in 1990 and is available in the market since 2000. The preparations are most often available in a concentration of $10-20 \%$ of the active susbstance. The present study showed varying effectiveness of repelling I. ricinus and $D$. reticulatus ticks by preparations containing $20 \%$ icaridin. Repellent efficacy of one of the two preparations for repelling I. ricinus ticks was $100 \%$ after 1.5 hours and $80 \%$ after 2,3 , and 4 hours; the second preparation showed inferior repellent efficacy - after 1.5 hours, the repellent efficacy was $60 \%$ and decreased after 3 hours to $30 \%$. The repellent efficacy of both preparations for $D$. reticulatus was higher than that for I. ricinus. The preparations showed 100\% effectiveness of repelling meadow ticks after 1.5 hours, and after the successive time intervals of 2, 3, and 4 hours, the effectiveness was approximately $80-85 \%$.

\section{PERMETHRIN}

In the 70s, the first pyrethroids were synthesized and characterized by greater durability than that of pyrethrum. Currently, they are a part of many insecticide preparations. An example is permethrin, which is used for the impregnation of clothing intended for use by the army, forestry workers, and hunters. Permethrin has a shortlasting repellent effect and a long-lasting killing effect. Among the various methods of impregnation of clothing
(DEET); ester etylowy kwasu 3-(N-acetylo-N-butylo) aminopropionowego (IR3535); kwas 1-piperydynokarboksylowy KBR3023 (ikarydyna), których skuteczność potwierdzona została w badaniach.

\section{DEET - N-N-DIETYLO-M-TOLUAMID}

DEET-N-N-dietylo-m-toluamid jest substancją aktywną wykazującą szerokie spektrum działania i najczęściej stosowaną jako składnik repelentów. Rynkowe preparaty odstraszające dostępne w Polsce zawierają najczęściej DEET w stężeniach od 7 do $35 \%$. W sprzedaży są również dostępne preparaty zawierające $50 \%$, a nawet $100 \%$ DEET przeznaczone do stosowania w szczególnych warunkach. Preparaty zawierające 30\% DEET zapewniają $100 \%$ ochronę przed kleszczami przez ponad 3 godziny (badania własne przeprowadzone na kleszczach $D$. reticulatus). DEET jest uważany za „złoty standard" w stosunku do innych repelentów. Jednak jest to substancja dość kontrowersyjna. W niektórych badaniach stwierdzono, że DEET łatwo i szybko wchłaniany jest przez ludzką skórę. Wchłanianie tej substancji odbywa się na poziomie $0,8 \% / \mathrm{h}$, ponadto substancja ta kumuluje się w skórze i tkankach thuszczowych przez 1-2 miesiące (29). W badaniach Wróblewskiej - Łuczki i wsp. dotyczących możliwości kumulacji DEET w organizmach leśników używających repelentów codziennie, w dawkach powtarzanych kilkukrotnie stwierdzono, że DEET nie gromadzi się w powierzchniowych warstwach skóry, jest wydalany z moczem i kałem (30). Stwierdzono także, że nadmierne lub niewłaściwe użycie produktów z tą substancją aktywną może wiązać się z następującymi efektami ubocznymi: encefalopatią, drgawkami, śpiączką, podrażnieniem skóry (31). Wyższe stężenia DEET rozpuszczają tworzywa sztuczne, dlatego nie należy stosować preparatów odstraszających z tą substancją na odzież, obuwie, itp.

\section{IR3535 (ESTER ETYLOWY KWASU 3-(N-ACETY- LO-N-BUTYLO)AMINOPROPIONOWEGO)}

Inną często wykorzystywaną w repelentach substancją aktywną jest IR3535 (ester etylowy kwasu 3-(N-acetylo-N-butylo-aminopropionowego) znana pod nazwą EBAAP. W Europie jest znana od 1970r, w USA od 1999r. Jest skuteczna nie tylko w stosunku do kleszczy, ale także komarów, much tse-tse (Glossinae), much końskich (Tabanidae) i meszek (Simullidae). IR3535 odstrasza również osy. Badania toksykologiczne wykazały, dobrą tolerancję dla skóry i ogólne bezpieczeństwo (32). W preparatach zarejestrowanych w Polsce ta substancja aktywna występuje najczęściej w stężeniu 7-20\%. W badaniach wykazano, że IR3535 zastosowany w preparatach w stężeniu 20\% wykazuje długo utrzymujący się efekt odstraszania kleszczy Amblyoma americanum - do 12 godzin (33). 
with permethrin, the method using polymer carriers at elevated temperature proved to be the most effective one. It has been shown that wearing clothes impregnated with this substance significantly reduced the risk of ticks' bites. Of the 138 I. ricinus ticks harvested during the study, only 6 were noted in volunteers wearing permethrin-impregnated clothing, and 132 ticks were found in volunteers wearing unimpregnated clothing. The repelling efficacy of the impregnated clothing was determined as $95.5 \%(34,35)$.

\section{PLANT-BASED ESSENTIAL OILS}

Repellent properties are also characteristics of some natural substances. The most frequently used are essential oils: citronella oil from lemon eucalyptus, lavender, anise, field mint, bergamot, lemon, camphor, coconut, cinnamon, clove, eucalyptus, geranium, nutmeg, orange flowers, pine, and thyme. However, their efficacy against ticks has been shown to be significantly lower than that of DEET (36). Increasing the concentration of oils may increase the effect of tick repellency, but high concentration, applied on the skin, may cause irritation and toxic effect on the human nervous system. Many plant products also have properties that are toxic to vertebrates, e.g., eugenol is a substance that irritates the eyes and skin and has been proven to be a mutagen; citronellol irritates eyes and is also a mutagen, which affects reproductive and nervous systems. Commercial repellents are available in various formulations, such as sprays, atomizers, lotions, gels, creams, tissues impregnated with a deterrent, PVC bracelets or silicone with cross-linked active substance, slices for sticking on clothing or other surfaces, and devices emitting ultrasound. The present study carried out at NIPH-NIH showed that some of the mentioned formulations do not ensure sufficient protection against ticks, e.g., bracelets containing citriodiol and slices additionally containing essential oils. Both products did not have a repellent effect on $D$. reticulatus ticks. During the testing of the repellent effect of the device emitting ultrasound, D. reticulatus ticks showed no response to the device (37). In the survey carried out by NIPH-NIH employees, spray formulations (47.9\%), fluid (12.4\%), and gel $(7.8 \%)$ dominated among the formulations purchased by respondents (8).

\section{PERFECT REPELLENT_SUMMARY}

The ideal repellent should have low toxicity for the user, that is, it should not cause skin irritation and allergy. It should provide full protection in the longest possible time, and hence, indirectly limit the spread of diseases transmitted by blood-borne arthropods. In addition, it should not destroy clothing, have a neutral odor, be easy to use, be commercially available, and

\section{IKARYDYNA}

Składnikiem repelentów bywa ikarydyna, znana również pod nazwą pikarydyna, KBR 3023 lub Bayrepel. Zsyntetyzowana w 1990 r., dostępna na rynku od 2000r. W preparatach najczęściej spotykana w stężeniu 10-20\%. Badania własne wykazały (w opracowaniu), że skuteczność odstraszania kleszczy I. ricinus i D. reticulatus przez preparaty zawierające $20 \%$ ikarydyny różniła się. Skuteczność odstraszania kleszczy I. ricinus jednego z preparatów wynosiła $100 \%$ po upływie 1,5 godziny, $80 \%$ po upływie 2, 3, 4 godzin, drugi preparat wykazał gorszą skuteczność odstraszania - po 1,5 godziny skuteczność odstraszania preparatu wyniosła $60 \%$ i malała, po upływie 3 godzin skuteczność odstraszania wyniosła 30\%. Skuteczność odstraszania $D$. reticulatus przez oba preparaty była wyższa w porównaniu do I. ricinus. Preparaty wykazały $100 \%$ skuteczności odstraszania kleszczy łąkowych po upływie 1,5 godziny, po upływie kolejnych przedziałów czasowych 2, 3, 4 godzin skuteczność wynosiła ok. 80-85\%.

\section{PERMETRYNA}

W latach 70. zsyntetyzowano pierwsze pyretroidy charakteryzujące się większą trwałością od pyretrum. Obecnie wchodzą one w skład wielu preparatów owadobójczych. Przykładem jest permetryna, stosowana do impregnacji odzieży przeznaczonej do użytku przez: wojsko, pracowników leśnych, myśliwych. Permetryna wykazuje krótkotrwałe działanie odstraszające oraz długotrwałe działanie zabijające. Wśród różnych metod impregnacji odzieży permetryną najbardziej skuteczna okazała się metoda z wykorzystaniem nośników polimerowych w podwyższonej temperaturze. Wykazano, że noszenie odzieży zaimpregnowanej tą substancją $\mathrm{w}$ znacznym stopniu zmniejszyło ryzyko ataku i ukłucia przez kleszcze. Na 138 kleszczy I. ricinus, odłowionych w czasie badania, tylko 6 odnotowano u ochotników noszących odzież zaimpregnowaną permetryną, zaś 132 kleszcze znaleziono na ochotnikach noszących odzież niezaimpregnowaną. Skuteczność odstraszania impregnowanej odzieży określono na 95,5 \% (34,35).

\section{OLEJKI ROŚLINNE}

Właściwościami repelentnymi odznaczają się także niektóre substancje naturalne. Najczęściej wśród nich wymieniane są olejki eteryczne: olejek citronellowy z eukaliptusa cytrynowego, lawendowy, anyżkowy, mięty polnej, bergamotowy, cytrynowy, kamforę, kokosowy, olejek cynamonowy, goździkowy, eukaliptusowy, geraniowy, muszkatołowy, z kwiatów pomarańczy, sosnowy, tymiankowy. Wykazano jednak, że ich skuteczność wobec kleszczy jest zdecydowanie mniejsza niż skuteczność DEET (36). Zwiększenie stężenia 
have a low price. The ideal repellent should also be safe for the environment. A repellent that would meet all these criteria is yet to be produced.

\section{REFERENCES}

1. Gliniewicz A, Karbowiak G, Mikulak E, et al. Impact of climate change on medically important ticks in Europe and their control. W: Dhang P (red.). Climate change impacts on urban pests. CABI, 2017a; 111-126

2. Gliniewicz A, Mikulak E, Przygodzka M. Methods of testing repelent efficiency against ticks, Przegl Epidemiol 2017; 71(3): 457-465

3. Kiewra D. Ocena wektorowej roli kleszczy Ixodes ricinus L. 1758 (Acari, Ixodidae) w transmisji krętków Borelia burgdorferi s.l. na terenie Polski, ze szczególnym uwzględnieniem Dolnego Śląska. I-BiS, Wrocław 2014

4. Del Fabbro S. Fencing and mowing as effective methods for reducing tick abundance on very small, infested plots. "Ticks and Tick - Borne Diseases, 2015; 6(2): 167-172

5. Gilbert L, Maffey GL, Ramsay SL et al. The effect of deer management on the abundance of Ixodes ricinus in Scotland. Ecol Appl 2012; 22(2): 658-67;

6. Cisak E. Borelioza i inne choroby przenoszone przez kleszcze $\mathrm{w}$ aspekcie narażenia zawodowego. Poradnik dla lekarzy. Oficyna Wydawnicza Instytutu Medycyny Pracy im. Prof. J. Nofera, Łódź 2010; 59-67;

7. Siuda K. Kleszcze (Acari: Ixodida) Polski. Część 1. Zagadnienia ogólne. PWN, Warszawa 1991;

8. Gliniewicz A, Mikulak E, Królasik A et al. Tick-bite preventative behaviour of people on recreational areas in Warsaw. Proc. 8th International Conference on Urban Pests, Zurich, 2014; p. 427

9. Buczek A, Bartosik K, Olszewski T, et al. Metody profilaktyki antykleszczowej stosowane przez mieszkańców Makroregionu Lubelskiego. W: Buczek A, Błaszak Cz (red): Stawonogi i żywiciele. Liber, Lublin 2003; 451- 462.

10. Asman M, Gąsior T, Jacek E, et al. Isolation of ricketssiae Anaplasma phagocytophilum and protozoans Babesia sp. in castor bean ticks (Ixodes ricinus) collected from patients of public helath centres on the territory of Upper Silesia. W: Buczek A, Błaszak Cz.(red.): Arthropods. The medical and economic importance. Akapit, Lublin 2012; 171-180;

11. Chmielewski T, Andrzejewski K, Mączka I, et al. Kleszcze zakażone bakteriami chorobotwórczymi dla człowieka na terenach parków miejskich Warszawy. Przegl Epidemiol 2011; 65: 577-581;

12. Wójcik-Fatla A, Szymańska J, Buczek A. Choroby przenoszone przez kleszcze. Część I. Ixodes ricinus jako rezerwuar i wektor patogenów. Zdr Publ, 2009; 119(2): 213-216

13. Nowak-Chmura M. Fauna kleszczy (Ixodida) Europy Środkowej. Wydawnictwo Naukowe Uniwersytetu Pedagogicznego, Kraków 2013;

14. Matuszkiewicz JM. Polands flora and fauna. W: Degórski M (red.): Natural and human environment of Poland: a geographical overview. PAN. IGiPZ, Warszawa 2006; 77-92; olejków może wzmóc efekt odstraszania kleszczy, lecz zbyt skoncentrowane, zaaplikowane na skórę mogą powodować jej podrażnienia i działać toksycznie na układ nerwowy człowieka. Wiele produktów roślinnych wykazuje także toksyczne właściwości dla kręgowców, np. eugenol jest substancją podrażniająca oczy oraz skórę i okazal się mutagenem; citronellol podrażnia oczy i również jest mutagenem, wpływa też negatywnie na rozrodczość i układ nerwowy.

Repelenty znajdujące się w sprzedaży są dostępne $\mathrm{w}$ różnych formulacjach, jako: spraye, płyny $\mathrm{w}$ atomizerach, lotiony, żele, kremy, chusteczki nasączane substancją odstraszającą, bransoletki z PCV lub silikonu z usieciowaną substancją aktywną, plasterki do naklejania na odzież lub inne powierzchnie, urządzenia emitujące ultradźwięki. Badania własne prowadzone w NIZP-PZH wykazały, że niektóre $\mathrm{z}$ wymienionych formulacji nie gwarantują wystarczającej ochrony przeciw kleszczom, np.: bransoletki zawierające citriodiol i plasterki dodatkowo zawierające olejki eteryczne. Oba produkty nie działały odstraszająco na kleszcze $D$. reticulatus . W trakcie badań działania odstraszającego urządzenia emitującego ultradźwięki zaobserwowano brak reakcji kleszczy $D$. reticulatus (37).

$\mathrm{W}$ ankiecie przeprowadzonej przez pracowników NIZP-PZH wśród form użytkowych zakupowanych przez respondentów dominowały preparaty do odstraszania w formie sprayu (47,9\%), płynu (12,4\%) i żelu (7,8\%) (8).

\section{IDEALNY REPELENT - PODSUMOWANIE}

Idealny repelent powinien - charakteryzować się niewielką toksycznością dla użytkownika, nie wywoływać podrażnień i alergizacji skóry. Powinien zapewniać pełną ochronę w ciągu jak najdłuższego czasu, a co za tym idzie, pośrednio ograniczać rozprzestrzenianie się chorób przenoszonych przez krwiopijne stawonogi. Ponadto powinien mieć neutralny zapach, nie niszczyć odzieży, być łatwy w użyciu, być ogólnie dostępny w sprzedaży, mieć niską cenę. Idealny repelent powinien być również bezpieczny dla środowiska.

Repelent, który spełniałby wszystkie wymienione kryteria niestety nie został jeszcze wyprodukowany.

15. Maetzel D, Maier WA., Kampen H. Borrelia burgdorferi infection prevalences in questing Ixodes ricinus ticks (Acari: Ixodidae) in urban and suburban Bonn, western Germany.Parasitol Res 2005; 95: 5-12;

16. Glaser B, Gothe R. Importierte arthropodenübertragene Parasiten und parasitische Arthropoden beim Hund. [Imported arthropod-borne parasites and parasitic arthropods in dogs. Species spectrum and epidemiologic analysis of the cases diagnosed in 1995/96]. "Tierarztliche Praxis. Ausgabe K, Kleintiere/ Heimtiere”, 1998; 26: 40-46; 
17. Wilhelmsson P, Lindblom P, Fryland L, et al. Ixodes ricinus ticks removed from humans in Northern Europe: seasonal pattern of infestation, attachment sites and duration of feeding. "Parasites \& Vectors", 2013; 6: 362;

18. Karbowiak G. Kleszcz łąkowy Dermacentor reticulatus - występowanie, biologia i rola jako wektora chorób odkleszczowych. Agencja Reklamowo-Wydawnicza Arkadiusz Grzegorczyk ,Warszawa 2009;

19. Földvári G, Široký P, Szekeres S, et al. Dermacentor reticulatus: a vector on the rise. "Parasites \& Vectors", 2016; 9: 314;

20. Földvári G, Rigó K, Lakos A. Transmission of Rickettsia slovaca and Rickettsia raoultii by male Dermacentor marginatus and Dermacentor reticulatus ticks to humans. Diagn Microbiol Inf Dis 2013; 76: 387-389;

21. Habalek i Halouzka, Distribution of Borrelia burgdorferi sensu lato genomic groups in Europe, a review, Eur J Epidemiol 1997; 13(8): 951-957

22. Tylewska - Wierzbanowska S, Chmielewski T. Tick-borne bacterial diseases in Poland, Part I. Zoonosis - Tick-Borne Diseases, Health Problems of Civilization 2017; 11(2): 56-65

23. Rauter C, Hartung T. Prevalence of Borrelia burgdorferi sensu lato genospecies in Ixodes ricinus ticks In Europe: a Metaanalysis, Appl and Environ Microbiol, 2005; 71(11): 7203-7216

24. Kmieciak W, Ciszewski M, Szewczyk E. Choroby odkleszczowe w Polsce- występowanie i trudności diagnostyczne, Med Pracy 2016; 67(1): 73-87

25. Centers of Disease Control and Prevention: What you need to known about Borrelia miyamotoi, https:/www. cdc.gov/ticks/miyamotoi.html, 18.08.2017

26. Kiewra D, Stańczak J, Richter M. Ixodes ricinus ticks (Acari, Ixodidae) as a vector of Borrelia burgdorferi sensu lato and Borrelia miyamotoi In Lower Silesia Poland preliminary study, Ticks Tick Born Dis 2014; 5: 892-897

27. Gupta PK, Rutledge LC. Role of repellents in vector control and disease prevention. Am J Trop Med and Hyg 1994; 50: 82-86;

28. Xue R, Ali A, Day J. Commercially available insect repellents and criteria for their use. W: Debboun M, Frances S, Strickman D (red). Insect Repellents. Principles, methods and uses. CRC Press, Boca Raton 2007; 405-416

29. Feldmann RJ, Maibach HI. Absorption of some organic compounds through the skin in man. J Invest Dermatol 1970; 54(5): 399-404;

30. Wróblewska- Łuczka P, Adamczuk P, Galińska E et al. Ocena narażenia leśników na akumulację w organizmie DEET pochodzącego z repelentów. W: Chmielewski J,
Florek-Łuszczki M, Springer M (red.): Troska o zdrowie - odpowiedzią na zagrożenia cywilizacyjne. Instytut Ochrony Środowiska-Państwowy Instytut Badawczy, Warszawa 2017; 213-222;

31. Frances SP. Efficacy and safety of repellents containing DEET. W: Debboun M., Frances SP, Strickman D (red): Insect Repellents. Pinciples, methods and uses. CRC Press, Boca Raton 2007, 311-321;

32. Puccetti G. IR 3535 (Etyl butylacetylaminopropionate). W: Debboun M, Frances S, Strickman D. (red.): Insect Repellents. Principles, methods and uses. CRC Press, Boca Raton 2007; 353-359;

33. Carroll JF, Benante JP, Kramer M, et al. Formulations of Deet, Picaridin, and IR3535 Applied to Skin Repel Nymphs of the Lone Star Tick (Acari: Ixodidae) for 12 Hours. J Med Entomol 2010; 47(4): 699-704;

34. Faulde MK, Uedelhoven WM, Malerius M, et al. Factory-based permethrin impregnation of uniforms: residual activity against Aedes aegypti and Ixodes ricinus in battle dress uniforms worn under field conditions, and cross-contamination during the laundering and storage process. "Military medicine", 2006; 171: 472-477;

35. Faulde MK, Scharninghausen J, Tisch M. Preventive of permethrin - impregnated clothing to Ixodes ricinus ticks and associated Borrelia burgdorferi s.1.. Germany Int J Med Microbiol 2008; 298 (1): 231-324;

36. Meng H, Li AY, Costa Junior LM, et al. Evaluation of DEET and eight essential oils for repellency against nymphs of the lone star tick, Amblyomma americanum (Acari: Ixodidae). "Exper and Appl Acarol 2016; 68(2): 241-249;

37. Gliniewicz A, Przygodzka M, Mikulak E. 2017c. Repelenty mogące stanowić zagrożenie dla zdrowia człowieka. II Ogólnopolska Konferencja Naukowa „Edukacja-Zdrowie-Środowisko”, Kielce, 1-2.06.2017, poster

Received: 17.12.2018

Accepted for publication: 29.04.2019

Otrzymano: 17.12.2018 r.

Zaakceptowano do publikacji: 29.04.2019 r.

\section{Address for correspondence: \\ Adres do korespondencji:}

Marta Przygodzka, Zakład Parazytologii i Chorób

Przenoszonych Przez Wektory.

Narodowy Instytut Zdrowia Publicznego - Państwowy

Zakład Higieny, ul. Chocimska 24 00-971 Warszawa,

e-mail: mprzygodzka@pzh.gov.pl 